\title{
Resource partitioning among Myoxocephalus sculpins, and their predator-prey relationships with Chionoecetes crabs in the eastern Bering Sea
}

\author{
Todd T. TenBrink*, Troy W. Buckley \\ Resource Ecology and Fisheries Management Division, Alaska Fisheries Science Center, National Marine Fisheries Service, \\ NOAA, 7600 Sand Point Way NE, Seattle, Washington 98115, USA
}

\begin{abstract}
Interspecific and intraspecific variation in the distributions and diets of congeneric sculpins, Myoxocephalus jaok, M. polyacanthocephalus, and M. scorpius, were described from data collected during summer trawl surveys of the eastern Bering Sea (EBS) continental shelf between 2000 and 2010 by the Alaska Fisheries Science Center (AFSC). Generalized additive models (GAMs) of abundance (count) and presence-absence data were applied separately for each species to examine the influence of selected factors (depth, bottom temperature, substrate type and location) on distribution and abundance. The final models indicated strong predictive relationships, suggesting habitat partitioning between species. Ontogenetic distributions were observed as larger individuals of each species tended to be associated with deeper depths and lower latitudes. Analysis of stomach contents indicated that these species consume a wide variety of prey and that the diet composition also shifted ontogenetically. Multivariate analyses of the mean percent weight $(\% \mathrm{~W})$ of 23 diet categories indicated that the diets differed among and within species. The diet of $M$. jaok consisted primarily of mysids, shrimps, and flatfish, with larger sculpins feeding on a greater amount of flatfish prey and less benthic infauna. Both M. polyacanthocephalus and M. scorpius fed considerably on commercially important Chionoecetes crabs, particularly C. opilio; however, similar-sized M. polyacanthocephalus consumed larger Chionoecetes prey than $M$. scorpius. Diets were more variable among smaller sculpins of these 2 species, and piscivory was more common among $M$. polyacanthocephalus. Habitat and diet partitioning were evident among species within this genus, as each species exhibited distinct spatial boundaries and diets, possibly avoiding inter- and intraspecific competition in this environment.
\end{abstract}

KEY WORDS: Resource partitioning - Distribution · Diet • Ontogeny • Myoxocephalus • Chionoecetes $\cdot$ Eastern Bering Sea

\section{INTRODUCTION}

A species' distribution is influenced by a host of biotic and abiotic factors. The co-occurrence of closely related species may be possible through different resource uses. Species may exhibit resource partitioning through their diet, such as feeding on different prey or proportions of the same prey, or through their distribution, by occupying different habitats, either spatially or temporally (Ross 1986). Observations of diet and habitat partitioning among related species are reported in many areas, including along rocky infralittoral systems (Sala \& Ballesteros 1997), tidepools (Davis 2000), deep sea communities (Carrasson \& Cartes 2002), continental shelves (Mabragana \& Giberto 2007), and large marine embayments (Fairclough et al. 2008). Studies on resource partitioning are vital to elucidate the ecological roles of closely related species in ecosystems for developing accurate considerations for ecosystem management.

In the eastern Bering Sea (EBS) shelf, 3 species of Myoxocephalus (Cottidae) are present in the demer- 
sal community: $M$. jaok, $M$. polyacanthocephalus, and $M$. scorpius (also known as $M$. verrucosus) (Mecklenburg et al. 2002). Sculpins constitute up to approx. $3 \%$ of the overall fish biomass (Lauth 2011). According to recent EBS survey estimates, the 3 Myoxocephalus species constitute nearly $70 \%$ of the reported $200000 \mathrm{t}$ of sculpins in this area (Ormseth \& TenBrink 2010). Despite their relative abundance and occurrence as bycatch in commercial bottom trawl and longline fisheries, their biology and ecology are poorly understood.

The diets of Myoxocephalus in the EBS have been generally described (Mito 1974, Hosoki 1978, Brodeur \& Livingston 1988), primarily with regard to their contribution to predation mortality of commercially important species, but examination of ontogenetic variation and diet comparisons among species have not been undertaken. Chionoecetes crabs (especially $C$. opilio) and walleye pollock Theragra chalcogramma are important prey of $M$. polyacanthocephalus (Mito 1974, Hosoki 1978, Brodeur \& Livingston 1988). Chionoecetes and other crabs are important diet components of $M$. scorpius (Hosoki 1978). The gravimetric diet composition reported for $M$. jaok by Hosoki (1978) — smelts and other fishes — is different than reported by Brodeur \& Livingston (1988): C. opilio, flatfishes, and unidentified fishes. Brodeur \& Livingston (1988) obtained diet information through shipboard scans during Alaska Fisheries Science Center (AFSC) surveys. However, confidence in correctly identifying species of Myoxocephalus by the AFSC prior to 2000 was not high (Stevenson \& Hoff 2009).

Myoxocephalus sculpins are recognized as important predators of Chionoecetes opilio and C. bairdi in the EBS (Mito 1974, Hosoki 1978, Brodeur \& Livingston 1988), both commercially important species. The overlap in spatial distribution between Chionoecetes crabs and Myoxocephalus predators occurs throughout much of the middle and outer continental shelf in the EBS (Chilton et al. 2011, Lauth 2011). While the relative size of predator and prey is often an important determinant in predator-prey relationships (e.g. Scharf et al. 2000), this aspect of Myoxocephalus predation on Chionoecetes crabs has not been described.

The main objectives of this study are to (1) report on the spatial segregation, size and depth distribution, and influence of environmental variables on the distribution and abundance patterns of Myoxocephalus species in the EBS; (2) provide updated diet information including size-specific diet descriptions and comparisons; (3) describe the predatory relationship each Myoxocephalus species has with commercially im- portant Chionoecetes crabs; and (4) demonstrate the partitioning among EBS Myoxocephalus based on their distributions and diets. From an ecosystem perspective, results from this study will provide an essential step toward understanding the biology of these common non-commercial predatory species.

\section{MATERIALS AND METHODS}

\section{Study area and survey design}

The distribution and abundance of fish and invertebrate species along the EBS shelf are monitored through annual AFSC bottom trawl research surveys (e.g. Lauth 2011). The standard bottom trawl survey area covers much of the EBS continental shelf from the $20 \mathrm{~m}$ isobath along the inner shelf to the $200 \mathrm{~m}$ isobaths, extending from the Alaskan Peninsula northward to approximately the latitude of St. Matthew Island (e.g. Lauth 2011). The EBS shelf has been surveyed by the AFSC using standard methods each summer since 1982 (Stauffer 2004), with 20 additional stations added to the survey in 1987. The sampling design is a fixed station design with 1 station at the center of a $20 \times 20$ nautical mile transect grid and 376 stations covering the survey area (Fig. 1). The same trawl sampling gear and target fishing time (30 $\mathrm{min}$ ) was employed during the survey. For 2010, the survey was expanded to include an additional 145 stations in the northern Bering Sea (NBS), which sampled areas north of $62^{\circ} \mathrm{N}$ (Lauth 2011)

These surveys have allowed researchers to gain an understanding of the annual summer condition of fish and crab populations, as well as patterns in physical conditions. The broad EBS shelf consists of 3 main oceanographic domains associated with bottom depths (inner, 0-50 m; middle, 50-100 m; and outer, 100-200 m), which are distinct regions exhibiting unique patterns of oceanic and biological processes (Bakkala 1993, Schumacher \& Stabeno 1998, Stabeno et al. 2001). An important, inter-annually variable feature in the EBS is a subsurface cold pool of water $\left(<2^{\circ} \mathrm{C}\right)$, formed by melting of the previous winter's sea ice, that can extend southward through the middle domain onto the southeastern EBS shelf.

\section{Data sources}

The AFSC's Resource Ecology and Ecosystems Modeling Program collects stomach samples on an 


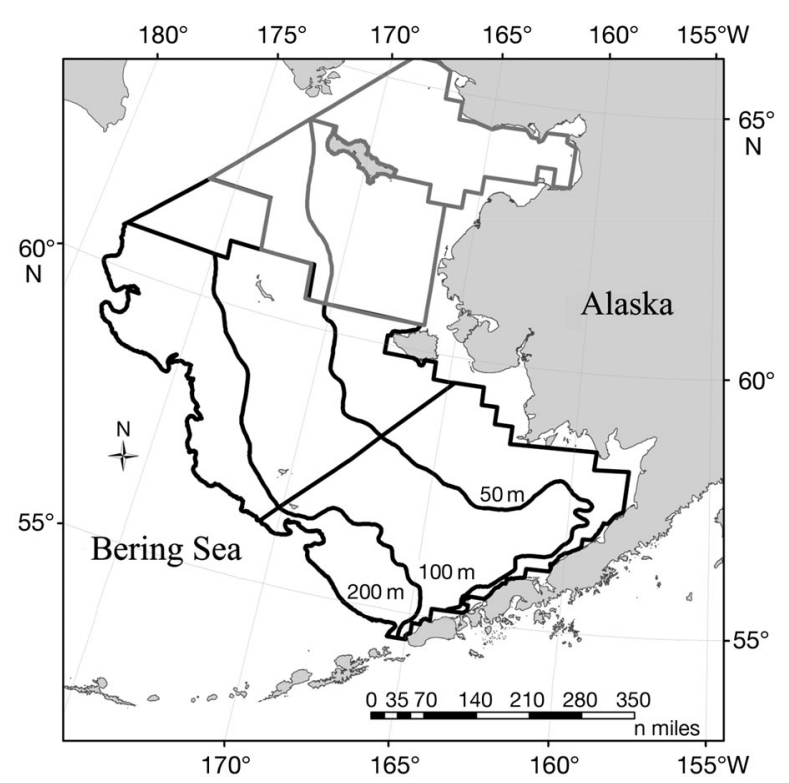

Fig. 1. Standard eastern Bering Sea survey (outlined in black) and the northern Bering Sea survey (outlined in gray) areas of the continental shelf. $\mathrm{n}$ miles: nautical miles

annual basis during the AFSC summer trawl surveys. Myoxocephalus sculpin diet data collected from stomachs during June through August from 2000 and 2006-2008 were used in the study. Specimens were collected opportunistically and via length-stratified sampling. Fish that showed signs of regurgitation (digested prey items inside the mouth, or a flaccid stomach) or net feeding (fresh prey items inside the mouth showing no signs of digestion) were excluded from sampling. Each stomach collected was excised and placed inside a cloth bag with a field tag labeled with specimen number, sex, species, fork length (FL) measured to the nearest $\mathrm{cm}$, haul number, vessel, and cruise. Samples were submerged and fixed in buffered $10 \%$ formalin seawater solution.

To describe Myoxocephalus distribution and explore habitat partitioning among species, we used AFSC survey data from 2000 to 2010, years of greater confidence in species identification (Stevenson \& Hoff 2009). Distribution and abundance were expressed as mean station catch per unit effort (CPUE, $\left.\mathrm{kg} \mathrm{ha}{ }^{-1}\right)$. At each station the size, number, and weight of specimens caught, bottom temperature (to the nearest $0.1^{\circ} \mathrm{C}$ ), and bottom depth (to the nearest $0.1 \mathrm{~m}$ ) were recorded. Substrate type from each station was obtained from Smith \& McConnaughey (1999), who designated 6 surficial sediment types based on relative distribution of grain sizes for the standard survey area: gravel; sand; mud; gravel and sand; sand and mud; gravel, sand and mud.

\section{Laboratory analysis}

Stomachs were transferred to a $70 \%$ ethanol mixture prior to analysis. Each stomach was cut open and its contents were removed, blotted dry, and weighed to the nearest $0.01 \mathrm{~g}$. Empty stomachs were noted. Stomach contents were examined with a binocular microscope, sorted, and the prey were identified to the lowest practical taxonomic level, counted and weighed. Prey that had clear cuts to the head or tail were identified as fishery offal (processing waste). The carapace widths of commercially important crabs were measured to the nearest $\mathrm{mm}$. Eggs were considered as 1 prey item when they occurred in a stomach (rather than the count of individual eggs). The following were used to quantify the importance of prey categories in non-empty stomachs: percent frequency of occurrence (\%FO), percent weight $(\% \mathrm{~W})$, and percent number $(\% \mathrm{~N})$ (Hyslop 1980).

\section{Statistical analysis}

We used generalized additive models (GAMs) to address the relationships between sculpin abundance and explanatory environmental variables (depth, bottom temperature, and substrate type) using pooled data from the standard EBS survey area (2000-2010, substratum data was not collected in the NBS). GAMs are non-parametric extensions of the generalized linear model that are able to deal with nonlinear relationships, and they allow more flexibility in the assumptions about the data than linear models (Hastie \& Tibshirani 1990). Our objective in this analysis was to make a general statement about the habitat of each species along the EBS shelf and show the degree of partitioning or selection by Myoxocephalus using GAMs. We tested how well the selected environmental variables defined habitat for each species. Typical of survey data, our dataset contained many zero values as each of the Муохоcephalus species were not caught in a number of stations over the course of the time period. We chose a 2-step GAM approach for analysis: (1) models using the response variable 'presence-absence' with a binary response $(1=$ presence; $0=$ absence) fitted with a binomial distribution and logit link function; and (2) models fitted with a quasi-Poisson distribution with a log-link function for the 'presence-only' (abundance) approach using count data (total number of fish caught at each EBS survey station). The quasi-likelihood approach is more suitable for overdispersed data (i.e. variance exceeds the mean) than 
classical Poisson because it assumes that the scale parameter of the distribution is unknown (Wood 2006). Count data was transformed $(\log (\operatorname{count}+1))$ before running the models. A constant of 1 was added to eliminate zero value points. Spatial autocorrelation was detected by the Mantel test (Fortin \& Gurevitch 1993), so we addressed this by incorporating a location covariate in universal transverse coordinates (UTMs: northing, easting) in the GAM models as a 2-dimensional non-linear effect (Wood 2006). Separate models were fit for each species. Models were constructed using the 'gam' function in the 'mgcv' package (Wood 2006) in R (v2.13.1). Thin plate regression splines were used for smoothing and the argument gamma $=1.4$ was used to avoid overfitting (Wood 2006). Efficiency of the smoothing parameters was estimated by minimizing the general cross validation (GCV) or un-biased risk estimator (UBRE). Model selection was based on the lowest score. A manual stepwise approach of the predictor variables was employed. Terms that were not significant $(\mathrm{p}<$ 0.05) during the stepwise approach were removed from the model.

The NBS was surveyed in 2010, allowing an investigation of ontogenetic shifts in distribution across the entire EBS shelf. We explored possible intraspecific variation among mean sizes of fish by depth and latitude. For latitude, each station was assigned a latitude category by rounding the end latitude to the nearest degree; for example, the $60^{\circ}$ category contained all specimens caught from stations from $59.5^{\circ}$ to $60.499^{\circ} \mathrm{N}$. Non-parametric tests (Mann-Whitney or Kruskal-Wallis) were conducted to test for significant differences in size by domain. Latitudinal trends were tested using linear regression.

Potential interspecific and intraspecific variation in the diets were assessed by multivariate statistical analyses of the \%W of 23 diet categories. One-way analysis of similarities (ANOSIM) (Clarke 1993) indicated that the overall diets of males and females of each species were similar ( $p>0.05)$, so all specimens were pooled for analyses. Non-metric multidimensional scaling (nMDS) ordination (2-dimensional stress) was used to investigate interspecific differences among the species. Prior to nMDS ordination, the mean \%W data was square-root transformed and the Bray-Curtis similarity measure was selected. Ontogenetic diet shifts were also investigated and were based on the following predator length classes: 16-25, 26-35, 36-45, 46-57, and 58+ cm FL. In our dataset, the 3 largest Myoxocephalus jaok individuals analyzed were under $58 \mathrm{~cm}$ FL, so these specimens were combined to form a $12 \mathrm{~cm}$ length class
(46-57 cm), consistent for all species, prior to analyses. Illustration of the diet composition ( $\% \mathrm{~N}$ and $\% \mathrm{~W}$ ) among length classes and species was presented using histograms of 12 broad diet categories, each making up $>10 \%$ of the stomach contents of at least 1 species-length class. For multivariate analyses, the mean \%W contribution for randomly allocated groups (= dietary samples) of individuals was calculated (e.g. Platell \& Potter 2001, Hourston et al. 2004, Marshall et al. 2008, Sommerville et al. 2011). Statistical significance was tested with ANOSIM. To determine which diet categories contributed to the greatest source of variation from these analyses, similarity percentages (SIMPER) were calculated (Clarke 1993). Multivariate statistics were conducted using PAST software (Hammer et al. 2001).

The relationship between Myoxocephalus sculpins and commercially important Chionoecetes crabs was examined for ontogenetic patterns and predator size to prey size relationships. The size frequency (measured as carapace width, $\mathrm{mm}$ ) of Chionoecetes prey consumed by different length classes of Myохоcephalus predators was compared to the size frequency of Chionoecetes crabs at each station. For this analysis, we used sequential $10 \mathrm{~cm}$ predator length classes (26-35, 36-45, 46-55, and 56+ cm FL). Size frequencies for Chionoecetes crabs were compiled from survey catch data at each station where sculpin stomach samples contained Chionoecetes crabs. Prey Chionoecetes include males, females, and individuals of undetermined sex. The size frequencies of males and females in the catch were calculated separately and smoothed using a running average of the \%FO for 3 carapace width categories before plotting. In addition, the carapace widths of $C$. opilio found in the stomachs of $M$. polyacanthocephalus and $M$. scorpius were regressed separately against predator sizes to examine the trend in average sizes of $C$. opilio eaten with increasing predator size. The slopes and intercepts of the regression equations were compared using an analysis of co-variance (ANCOVA).

\section{RESULTS}

\section{Distribution}

Although spatial overlap occurred in some areas of the EBS shelf, the distribution and peak abundance from mean CPUE maps of Myoxocephalus indicated spatial segregation among the 3 species (Fig. 2). $M$. jaok was most abundant along the inner domain, and much less abundant across the middle and the outer 
domains. M. polyacanthocephalus was more broadly distributed across the shelf, less abundant across the central middle domain, and rare in the NBS. The peak abundance of $M$. scorpius was observed mainly along the central middle shelf and in the NBS.

The final GAMs for both the presence-absence and presence-only approaches performed well, according to the $\%$ of the observed deviance (Table 1). The categorical variable substrate was a significant term in just 1 of the final models (count data for Myoxocephalus jaok; $\mathrm{p}=0.035)$. For the presence-absence approach, there was some variation in the final model terms between species and the smoothing plots generally showed similar patterns to the plots from the quasi-approach. Notably, the presence of M. jaok showed a steep linear decline with depth and the presence of $M$. scorpius exhibited a near-linear decline from colder to warmer bottom temperatures.

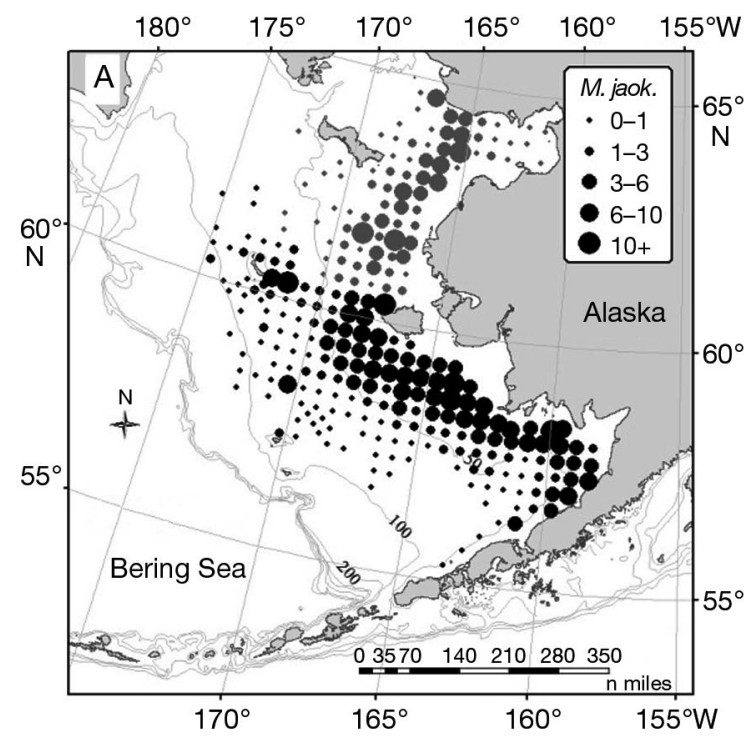

Fig. 2. Spatial distribution and abundance (mean CPUE, $\mathrm{kg} \mathrm{ha}^{-1}$ ) for (A) Myoxocephalus jaok; (B) M. polyacanthocephalus; and (C) $M$. scorpius. Black circles represent mean CPUE from 2000-2010 from the eastern Bering Sea; gray circles represent mean CPUE from the northern Bering Sea in 2010 (same units). $\mathrm{n}$ miles: nautical miles
The best model for the quasi-Poisson approach using count data for each species consisted of the same 3 significant factors, including the 2dimensional location effect. The smoothing plots of the 1-dimensional terms from the final models (depth and temperature) indicated unique trends among species (Fig. 3). Myoxocephalus jaok abundance showed a decline with depth, but increased when bottom temperatures were above $2^{\circ} \mathrm{C}$, with the exception of a few stations where temperatures averaged near $0^{\circ} \mathrm{C}$, where a moderate number were caught. Numbers of $M$. polyacanthocephalus appeared to peak between depths of 50 and $100 \mathrm{~m}$ with a gradual decline observed in deeper waters and at bottom temperatures near $2^{\circ} \mathrm{C}$. M. scorpius was clearly most abundant between the depths of 50 and $100 \mathrm{~m}$ and at bottom temperatures below $2{ }^{\circ} \mathrm{C}$.

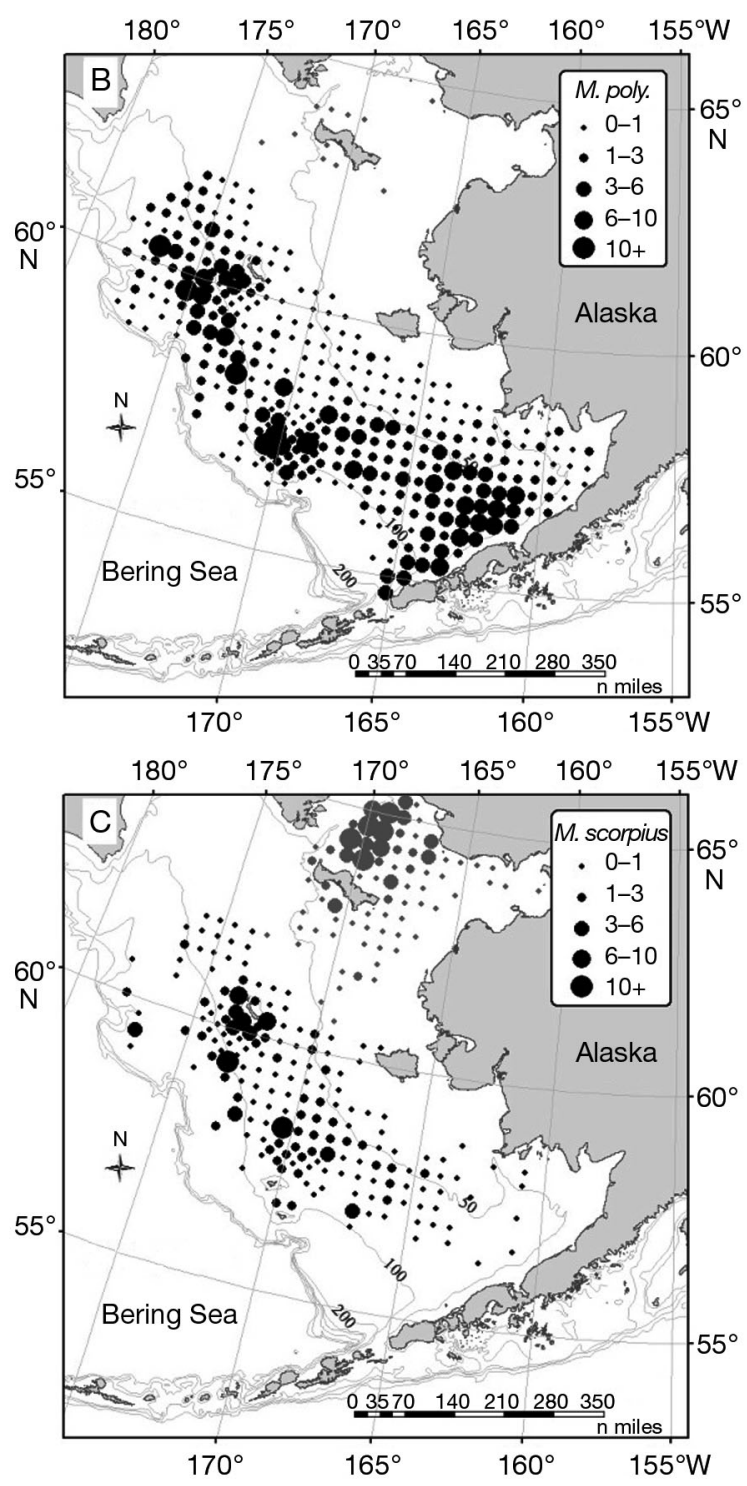


Table 1. Generalized additive model (GAM) results from best fitting models. Full model: Myoxocephalus presence-absence/ $\log ($ count +1$) \sim$ substrate type $+\mathrm{s}($ Depth $)+\mathrm{s}$ (Bottom temperature) $+\mathrm{s}$ (Northing, Easting). Values corresponding to the individual smooth terms (s) are the estimated degrees of freedom. UBRE: unbiased risk estimator, used in the Binomial models; GCV: general cross validation, used in the quasi-Poisson models. Approximate significance of smooth terms from the final model output summary: ${ }^{*} \mathrm{p}<0.05 ;{ }^{* *} \mathrm{p}<0.01{ }_{i}{ }^{* * *} \mathrm{p}<0.001$

\begin{tabular}{|lcccccc|}
\hline & \multicolumn{2}{c}{ M. jaok } & \multicolumn{2}{c}{ M. polyacanthocephalus } & \multicolumn{2}{c}{ M. scorpius } \\
& Presence-absence & Count & Presence-absence & Count & Presence-absence & Count \\
\hline Family & Binomial & Quasi-Poisson & Binomial & Quasi-Poisson & Binomial & Quasi-Poisson \\
Link function & Logit & Log & Logit & Log & Logit & Log \\
$\mathrm{R}^{2}$ (adjusted) & 0.797 & 0.921 & 0.442 & 0.479 & 0.616 & 0.736 \\
Deviance explained (\%) & 77.5 & 91.3 & 47.4 & 53.5 & 57.3 & 76.5 \\
UBRE/GCV & -0.553 & 0.164 & -0.555 & 0.311 & -0.281 & 0.293 \\
Substrate & - & - & - & - & - & - \\
s(Depth) & $1.00^{* * *}$ & $5.38^{* * *}$ & $3.89^{* * *}$ & $5.72^{* * *}$ & $4.55^{*}$ & $7.08^{* * *}$ \\
s(Bottom temperature) & - & $5.22^{* * *}$ & $4.57^{* * *}$ & $6.79^{* * *}$ & $1.53^{* * *}$ & $2.78^{* *}$ \\
s(Northing,Easting) & $16.10^{* * *}$ & $12.85^{* * *}$ & - & $21.07^{* * *}$ & $10.09^{* * *}$ & $17.12^{* * *}$ \\
\hline
\end{tabular}
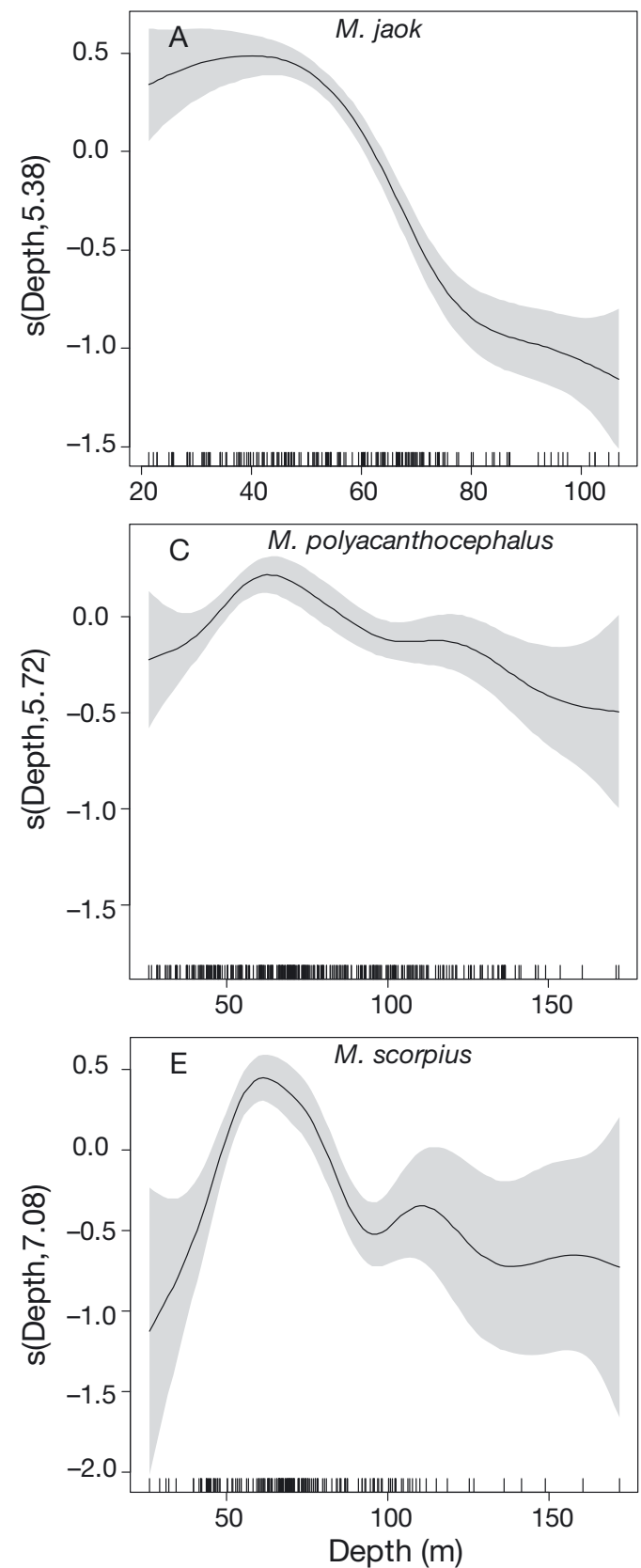
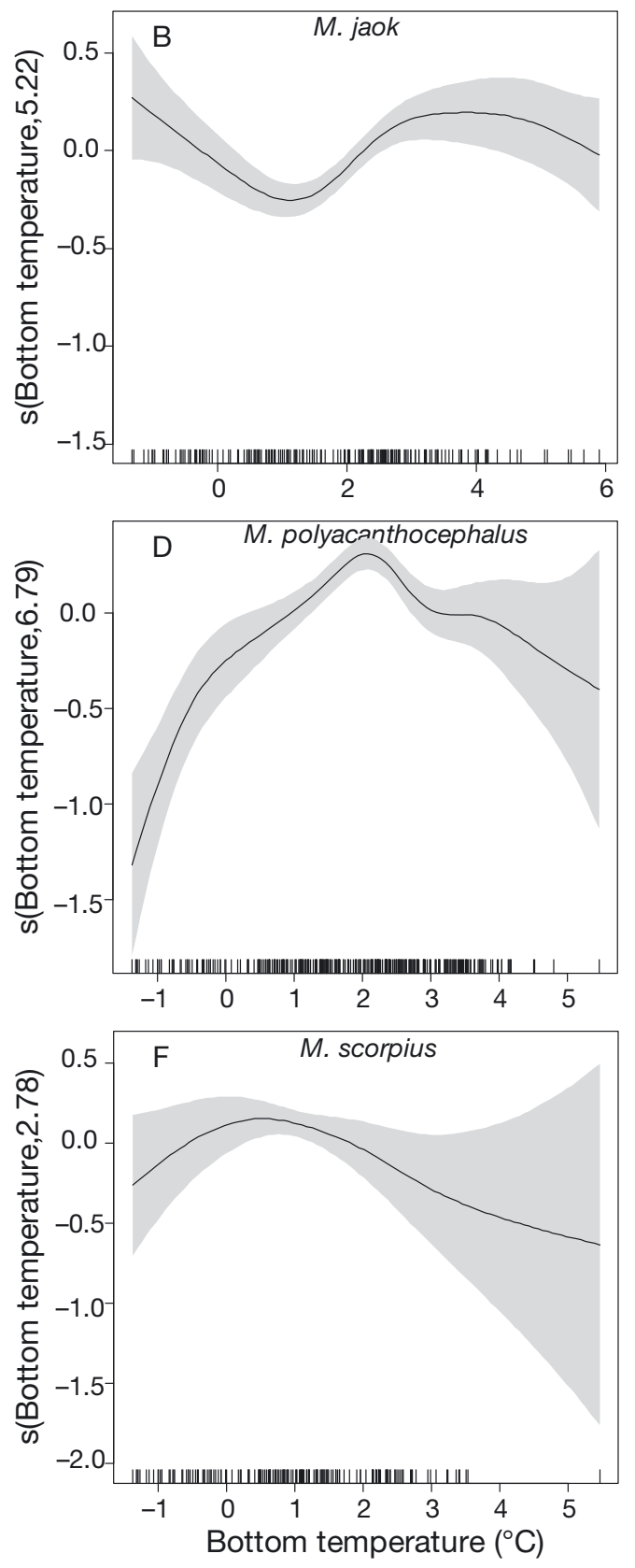


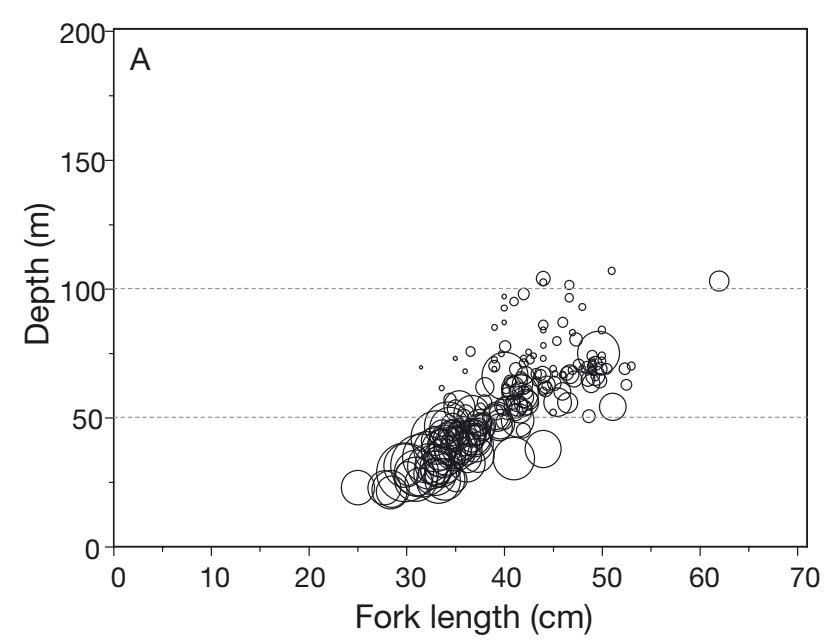

Fig. 4. Size vs. mean station bottom depth distribution for those survey stations that encountered (A) Myoxocephalus jaok; (B) M. polyacanthocephalus; and (C) M. scorpius. Circles represent a station, while the size of the circle denotes the proportion of weight of fish caught relative to other stations. Dashed horizontal lines represent the 50 and $100 \mathrm{~m}$ isobaths along the eastern Bering Sea shelf. Points along abscissas refer to the mean fork length $(\mathrm{cm})$ caught at each station

There was evidence of ontogenetic migration by depth and latitude for each species. Mean sizes increased with depth for Myoxocephalus jaok (MannWhitney, $\mathrm{p}<0.01$ ), M. polyacanthocephalus (KruskalWallis, $\mathrm{p}<0.01$ ) and M. scorpius (Kruskal-Wallis, $\mathrm{p}<$ 0.01) (Fig. 4). A latitudinal gradient was evident (Fig. 5) as mean sizes were significantly smaller at higher latitudes $(M$. jaok, p $<0.05 ;$ M. polyacanthocephalus, $\mathrm{p}<0.001$; M. scorpius, $\mathrm{p}=0.002$ ).

\section{Diet}

General observations and comparisons

A total of 517 stomachs were collected and examined, of which $93 \%(\mathrm{n}=482)$ contained prey items. For the 3 sculpin species combined, 85 separate prey
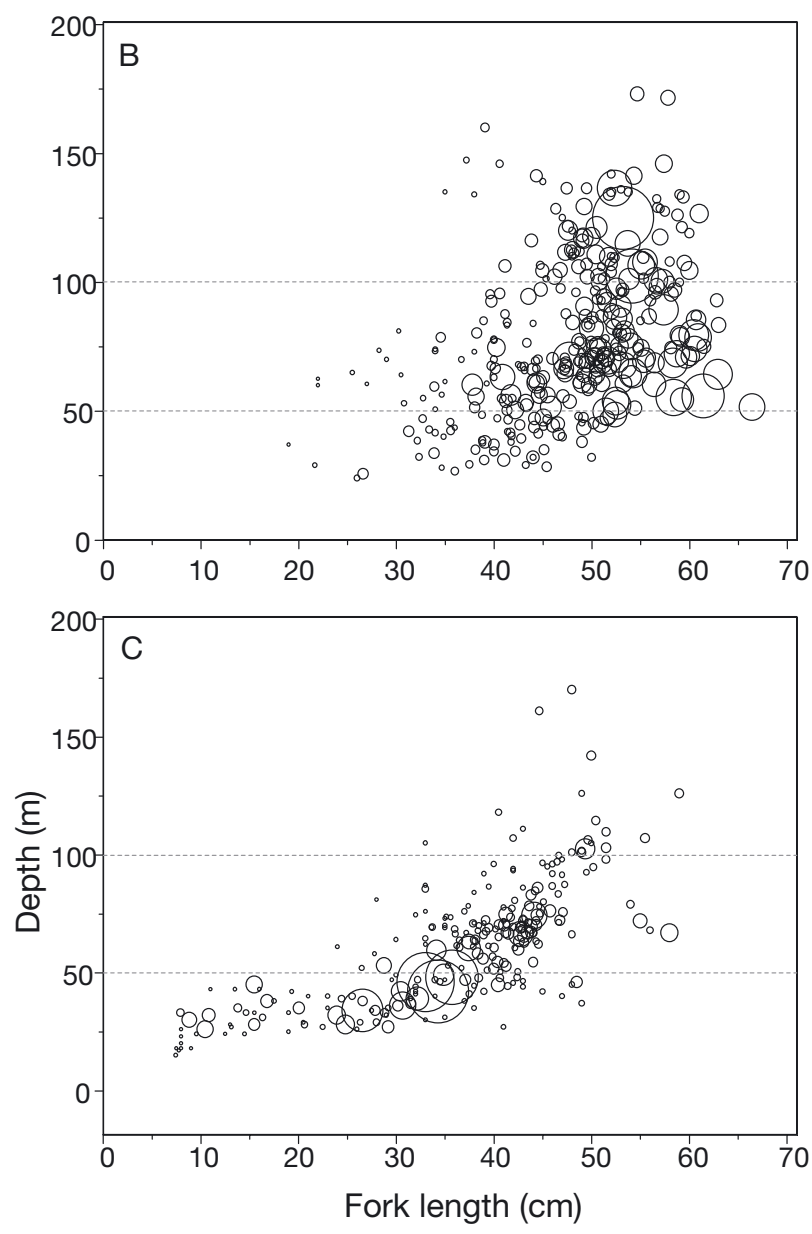

types (including different taxonomic levels) were identified from the stomach contents examined (Table 2). In general, the smaller-sized individuals of all 3 species had a varied diet, consuming many different types of smaller prey, while larger-sized individuals consumed fewer types of larger prey. Numerically important prey of Myoxocephalus jaok were crangonid shrimp and mysids, while pleuronectoids (flatfishes) were gravimetrically dominant, and these 3 prey types had the highest \%FO (Table 2). The diet of $M$. polyacanthocephalus was diverse, but Chionoecetes crabs were the dominant prey in terms of $\% \mathrm{FO}, \% \mathrm{~N}$ and $\% \mathrm{~W}$, and a variety of fishes and fishery offal were of secondary importance. Similarly, the diet of $M$. scorpius was dominated by Chionoecetes crabs in terms of \%FO and \%W, while prey items of secondary importance were mostly other crabs, shrimp and polychaete worms.

Fig. 3. One-dimensional smoothing plots for the predicted abundance of each species from the quasi-Poisson final models for (A,B) Myoxocephalus jaok, (C,D) M. polyacanthocephalus and (E,F) M. scorpius. Shaded areas in the plots represent the $95 \%$ confidence interval boundaries around the covariate main effect. The density of the data points is represented by a 'rug' along the $X$-axis. $Y$-axis labels represent the smooth term (s) of each covariate and its associated estimated degree of freedom 


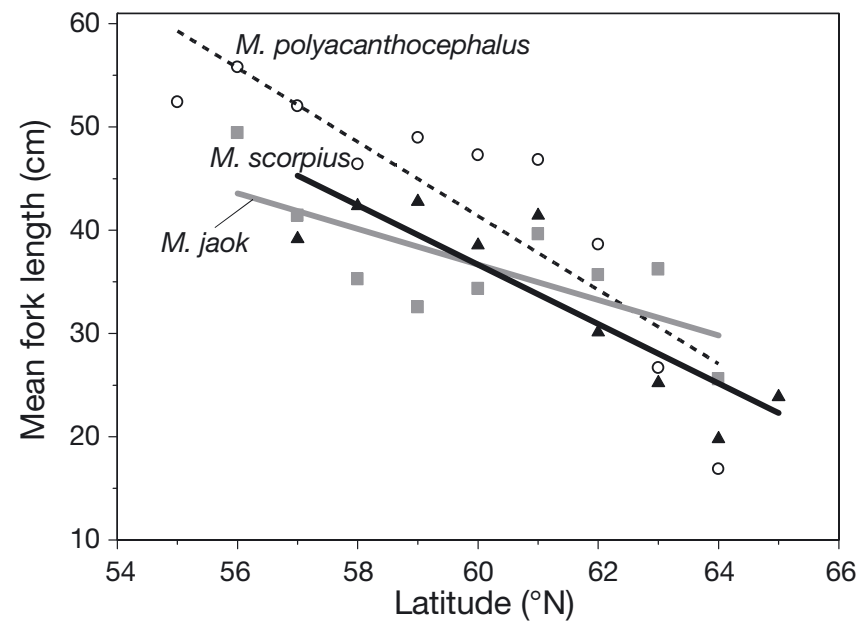

Fig. 5. Regression of mean size of Myoxocephalus vs. latitude. M. jaok (匹, gray line), M. polyacanthocephalus $(\mathrm{O}$, dashed line), and $M$. scorpius $(\boldsymbol{\Lambda}$, black line $)$

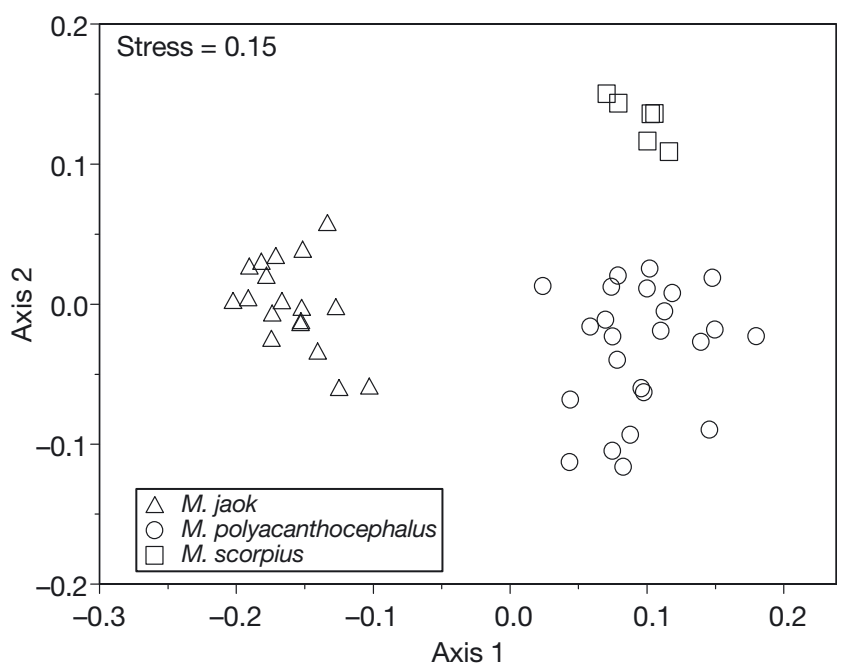

Fig. 6. Non-metric multidimensional scaling (nMDS) ordination comparing the interspecific relationships of the mean weight composition (\%W) of the diets between Myoxocephalus jaok $(\Delta), M$. polyacanthocephalus (O), and M. scorpius $(\square)$. Each point represents 10 individuals (= dietary sample)

Dietary samples formed separate groups by species in the nMDS ordination plot (Fig. 6), indicating no significant interspecific diet overlap by overall diet composition by mean \%W (ANOSIM, R-statistic = 0.914, $\mathrm{p}<0.001$ ). Comparisons among species indicated that the diet of Myoxocephalus jaok differed most from its congeners. This difference was high when compared with $M$. polyacanthocephalus (Rstatistic $=0.964, \mathrm{p}<0.001$, dissimilarity $=73.3 \%)$ and M. scorpius (R-statistic $=0.998, \mathrm{p}<0.001$, dissimilarity $=81.2 \%$ ). According to SIMPER analysis, 2 major contributory factors in this difference were Chionoe- cetes crabs, consumed heavily by $M$. polyacanthocephalus and $M$. scorpius but non-essential in the diet of $M$. jaok, and flatfish, which were largely consumed only by $M$. jaok. The diet also differed between $M$. polyacanthocephalus and $M$. scorpius (ANOSIM, R-statistic $=0.628, \mathrm{p}<0.001$, dissimilarity $=57.1 \%$ ). SIMPER analysis showed that Chionoecetes crabs were a major contributory factor in this difference, as they made up a larger percentage of the diet in M. scorpius. Flatfish and gadids also contributed to this observed difference based on their relative importance in the diet of $M$. polyacanthocephalus. Other notable differences include fishery offal, which was relatively important in the diet of $M$. polyacanthocephalus, but was not found in the diet of M. scorpius, and Hyas crabs, which were the second most important prey of $M$. scorpius but were of lesser importance in the diet of $M$. polyacanthocephalus (Table 2).

Ontogenetic shifts in the diet were identified within each of the 3 Myoxocephalus species (Fig. 7). The numerically most important diet component of $M$. jaok shifted with increasing predator size, from mysids and small crustaceans to crangonid shrimp to flatfish. Owing to the larger size of flatfish prey, this shift in \%W was more pronounced. Pair-wise ANOSIM diet comparisons indicated significant differences among the length classes except between the 26-35 cm and 36-45 cm length classes of M. jaok (dissimilarity $=39.3 \%$ ) (Table 3$)$. Shifts in the diet components with increasing size of $M$. polyacanthocephalus appeared less pronounced than for the other 2 species, but zoarcid prey tended to decrease and scavenging on fishery offal tended to increase over the predator sizes sampled. Pair-wise ANOSIM diet comparisons indicated significant differences among the length classes except between the 36-45 $\mathrm{cm}$ and $46-57 \mathrm{~cm}$ length classes of $M$. polyacanthocephalus (dissimilarity $=45.9 \%$ ) (Table 3 ). The diet of M. scorpius shifted from an wide array of diet components to almost exclusively Chionoecetes crabs, in terms of both $\% \mathrm{~N}$ and $\% \mathrm{~W}$, with increasing predator size. Pair-wise ANOSIM diet comparisons indicated significant differences among the 3 length classes (Table 3).

\section{Myoxocephalus - Chionoecetes relationships}

Chionoecetes crabs were considerably less important in the diet of Myoxocephalus jaok than M. polyacanthocephalus and M. scorpius (Table 2). A small percentage $(6 \%)$ of $M$. jaok stomachs examined con- 
Table 2. Percent frequency of occurrence $(\% \mathrm{FO})$, percent number $(\% \mathrm{~N})$, and percent weight $(\% \mathrm{~W})$ of prey categories in the diets of 3 Муохосеphalus species in the eastern Bering Sea. ${ }^{*}$ Prey categories that represent aggregates of multiple species, and/or identification levels of the stomach contents

\begin{tabular}{|c|c|c|c|c|c|c|c|c|c|}
\hline \multirow[t]{2}{*}{ Prey category } & \multicolumn{3}{|c|}{ M. jaok } & \multicolumn{3}{|c|}{ M. polyacanthocephalus } & \multicolumn{3}{|c|}{ M. scorpius } \\
\hline & $\% \mathrm{FO}$ & $\% \mathrm{~N}$ & $\% \mathrm{~W}$ & $\% \mathrm{FO}$ & $\% \mathrm{~N}$ & $\% \mathrm{~W}$ & $\% \mathrm{FO}$ & $\% \mathrm{~N}$ & $\% \mathrm{~W}$ \\
\hline Hydroida $^{a}$ & & & & 0.42 & 0.11 & 0.00 & & & \\
\hline Polychaeta $^{\mathrm{b}, *}$ & 12.29 & 2.08 & 0.14 & 3.77 & 1.12 & 0.03 & 35.94 & 15.15 & 0.95 \\
\hline Hirudinea $^{a}$ & & & & & & & 1.56 & 0.14 & 0.01 \\
\hline Gastropoda $^{\mathrm{c}, *}$ & 2.79 & 0.35 & 0.05 & 1.26 & 0.34 & 0.13 & 4.69 & 0.41 & 0.06 \\
\hline Bivalvia $^{\mathrm{c}, *}$ & & & & 3.77 & 1.79 & 0.03 & 1.56 & 0.14 & 0.00 \\
\hline Cephalopoda $^{\mathrm{d}, *}$ & & & & 6.69 & 1.79 & 0.59 & & & \\
\hline Unident. crustacea $^{\mathrm{a}}$ & & & & & & & 1.56 & 0.14 & 0.00 \\
\hline Mysidae $^{\mathrm{e}}$ & 38.55 & 30.20 & 1.50 & 1.26 & 0.34 & 0.00 & & & \\
\hline Isopoda $^{f}$ & & & & 0.84 & 1.56 & 0.03 & & & \\
\hline Gammaridea $^{\mathrm{f}}$ & 1.68 & 0.21 & 0.00 & 0.42 & 0.11 & 0.00 & 12.50 & 6.06 & 0.24 \\
\hline Unident. shrimp ${ }^{g, *}$ & 2.79 & 0.35 & 0.02 & 2.51 & 0.67 & 0.01 & 17.19 & 5.37 & 0.77 \\
\hline Hippolytidae $^{\mathrm{h}_{1 *}}$ & 0.56 & 0.07 & 0.01 & 1.67 & 0.89 & 0.01 & 35.94 & 19.14 & 2.32 \\
\hline Pandalidae $^{\mathrm{i}_{, *}}$ & 1.68 & 0.21 & 0.18 & 0.84 & 0.22 & 0.06 & 26.56 & 4.68 & 1.47 \\
\hline Crangonidae $^{\mathrm{j}_{\text {,**}}}$ & 71.51 & 39.24 & 9.77 & 5.44 & 3.35 & 0.08 & 9.38 & 0.83 & 0.18 \\
\hline Unident. $\mathrm{crab}^{\mathrm{k}}$ & 2.79 & 0.35 & 0.10 & 2.51 & 0.78 & 0.21 & 15.63 & 1.79 & 3.31 \\
\hline Paguridae $^{1, *}$ & 1.12 & 0.14 & 0.36 & 7.53 & 2.12 & 0.65 & 23.44 & 3.31 & 6.95 \\
\hline Munida quadrispina $^{\mathrm{k}}$ & & & & & & & 1.56 & 0.14 & 0.10 \\
\hline Lithodidae $^{\mathrm{k}}$ & 0.56 & 0.07 & 0.08 & & & & & & \\
\hline Majidae $^{\mathrm{m}}$ & 0.56 & 0.14 & 1.32 & 3.35 & 1.23 & 0.62 & 21.88 & 2.90 & 6.94 \\
\hline Oregonia sp. ${ }^{\mathrm{m}}$ & 0.56 & 0.07 & 0.03 & 0.84 & 0.22 & 0.04 & & & \\
\hline Hyas sp. ${ }^{\mathrm{n}, *}$ & 3.91 & 0.70 & 3.30 & 8.37 & 4.02 & 3.07 & 28.13 & 7.31 & 14.62 \\
\hline Chionoecetes sp. ${ }^{\circ, *}$ & 7.26 & 1.81 & 5.66 & 69.04 & 49.61 & 50.69 & 62.50 & 20.66 & 57.51 \\
\hline Erimacrus isenbeckii ${ }^{\mathrm{k}}$ & & & & 0.42 & 0.11 & 0.01 & & & \\
\hline Echiura $^{\mathrm{b}}$ & 1.12 & 0.14 & 0.02 & 1.67 & 0.56 & 0.03 & 6.25 & 1.52 & 1.59 \\
\hline Ophiurida $^{\mathrm{a}}$ & & & & 3.77 & 1.01 & 0.01 & 1.56 & 0.14 & 0.02 \\
\hline Holothuroidea $^{a}$ & & & & 0.42 & 0.11 & 0.07 & & & \\
\hline Urochordata $^{\mathrm{a}}$ & & & & 0.84 & 0.22 & 0.01 & & & \\
\hline Teleostei ${ }^{\mathrm{p}, *}$ & 18.44 & 2.71 & 1.36 & 10.46 & 2.90 & 0.38 & 35.94 & 8.13 & 0.93 \\
\hline Teleost eggs $^{p}$ & & & & 0.84 & 0.11 & 0.29 & & & \\
\hline Clupea pallasii ${ }^{\mathrm{q}}$ & 6.70 & 1.04 & 5.18 & 2.09 & 0.78 & 0.47 & 4.69 & 0.55 & 0.15 \\
\hline Mallotus villosus ${ }^{\mathrm{q}}$ & 2.79 & 0.42 & 1.13 & & & & & & \\
\hline Gadidae $^{r_{*} *}$ & 8.38 & 1.53 & 1.59 & 11.30 & 3.69 & 12.04 & 6.25 & 0.83 & 0.79 \\
\hline Zoarcidae $^{\mathrm{s}, *}$ & & & & 21.76 & 9.61 & 4.14 & 1.56 & 0.14 & 0.14 \\
\hline Pleurogrammus monopterygius ${ }^{\mathrm{q}}$ & & & & 0.42 & 0.11 & 2.44 & & & \\
\hline Cottoidei $^{\mathrm{t}}$ & 1.68 & 0.21 & 0.09 & & & & 1.56 & 0.14 & 0.02 \\
\hline Cottidae $^{\mathrm{t}, *}$ & 2.79 & 0.35 & 0.82 & & & & & & \\
\hline Psychrolutidae $e^{\mathrm{t}, *}$ & & & & 0.42 & 0.11 & 0.07 & 1.56 & 0.14 & 0.72 \\
\hline Agonidae $\mathrm{u}^{\mathrm{u}_{*}}$ & 3.91 & 0.70 & 3.48 & 3.35 & 0.90 & 0.96 & & & \\
\hline Cyclopteridae $^{q_{*} *}$ & 1.12 & 0.14 & 3.96 & & & & 1.56 & 0.14 & 0.03 \\
\hline Stichaeidae ${ }^{q_{1} *}$ & 0.56 & 0.07 & 0.13 & 0.42 & 0.11 & 0.00 & & & \\
\hline Ammodytes hexapterus ${ }^{\mathrm{q}}$ & 4.47 & 0.63 & 0.99 & & & & 1.56 & 0.14 & 0.16 \\
\hline Pleuronectoidei $^{\mathrm{v}, *}$ & 62.01 & 16.03 & 56.97 & 14.64 & 5.70 & 11.18 & & & \\
\hline Fishery offal ${ }^{\mathrm{w}}$ & 0.56 & 0.07 & 1.79 & 4.18 & 3.24 & 10.93 & & & \\
\hline Unident. eggs ${ }^{\mathrm{a}}$ & & & & 0.84 & 0.22 & 0.72 & & & \\
\hline Unident. jelly ${ }^{\mathrm{a}}$ & & & & 0.42 & 0.11 & 0.00 & & & \\
\hline Unident. algae $^{\mathrm{a}}$ & & & & 0.42 & 0.11 & 0.01 & & & \\
\hline $\begin{array}{l}{ }^{\mathrm{a}} \text { Other stomach contents were } \\
{ }^{\mathrm{d}} \text { Cephalopoda, }{ }^{\mathrm{e}} \text { Mysidae, }{ }^{\mathrm{f}} \text { other } \\
\text { shrimp, }{ }^{\mathrm{k}}{ }^{\mathrm{u}} \text { unidentified and other } \mathrm{c} \\
\text { spp. crabs, }{ }^{\mathrm{p}} \text { unidentified fish, }{ }^{\mathrm{q}} \text { ot } \\
\text { and }{ }^{\mathrm{w}} \text { offal }\end{array}$ & $\begin{array}{l}\text { the } 23 \\
\text { small cr } \\
\text { rabs, }{ }^{1} \mathrm{po} \\
\text { her iden }\end{array}$ & $\begin{array}{l}\text { diet } \\
\text { ustace } \\
\text { gurid c } \\
\text { tified } \mathrm{f}\end{array}$ & $\begin{array}{l}\text { gorles } \\
\text { gunid } \\
\mathrm{s}_{1}{ }^{\mathrm{m}} \text { un } \\
{ }^{\mathrm{r}} \text { gadi }\end{array}$ & $\begin{array}{l}\text { in mu } \\
\text { shrim } \\
\text { ed and } \\
\text { oarcid }\end{array}$ & $\begin{array}{l}\text { ariate } \\
\text { aippo } \\
\text { er me } \\
\mathrm{n}^{\mathrm{t}}{ }^{\mathrm{t}} \mathrm{cot}\end{array}$ & $\begin{array}{l}\text { analyse } \\
\text { id shriı } \\
\text { d crabs } \\
\text { id fish, }\end{array}$ & $\begin{array}{l}\text { like, } \\
\text { lid sh } \\
\text { crab } \\
\text { h, vpl }\end{array}$ & $\begin{array}{l}\text { her } \mathrm{n} \\
\mathrm{hp}^{\mathrm{j}}{ }^{\mathrm{j}} \mathrm{Cr} \\
\text { Chio } \\
\text { ronec }\end{array}$ & $\begin{array}{l}\text { llusca, } \\
\text { ngonid } \\
\text { ecetes } \\
\text { id fish, }\end{array}$ \\
\hline
\end{tabular}


tained Chionoecetes crabs. All 3 species, however, including all length classes of $M$. polyacanthocephalus and $M$. scorpius, consumed more female than male Chionoecetes crabs. There were also more female than male Chionoecetes crabs in the environment where predation on these crabs was found. The
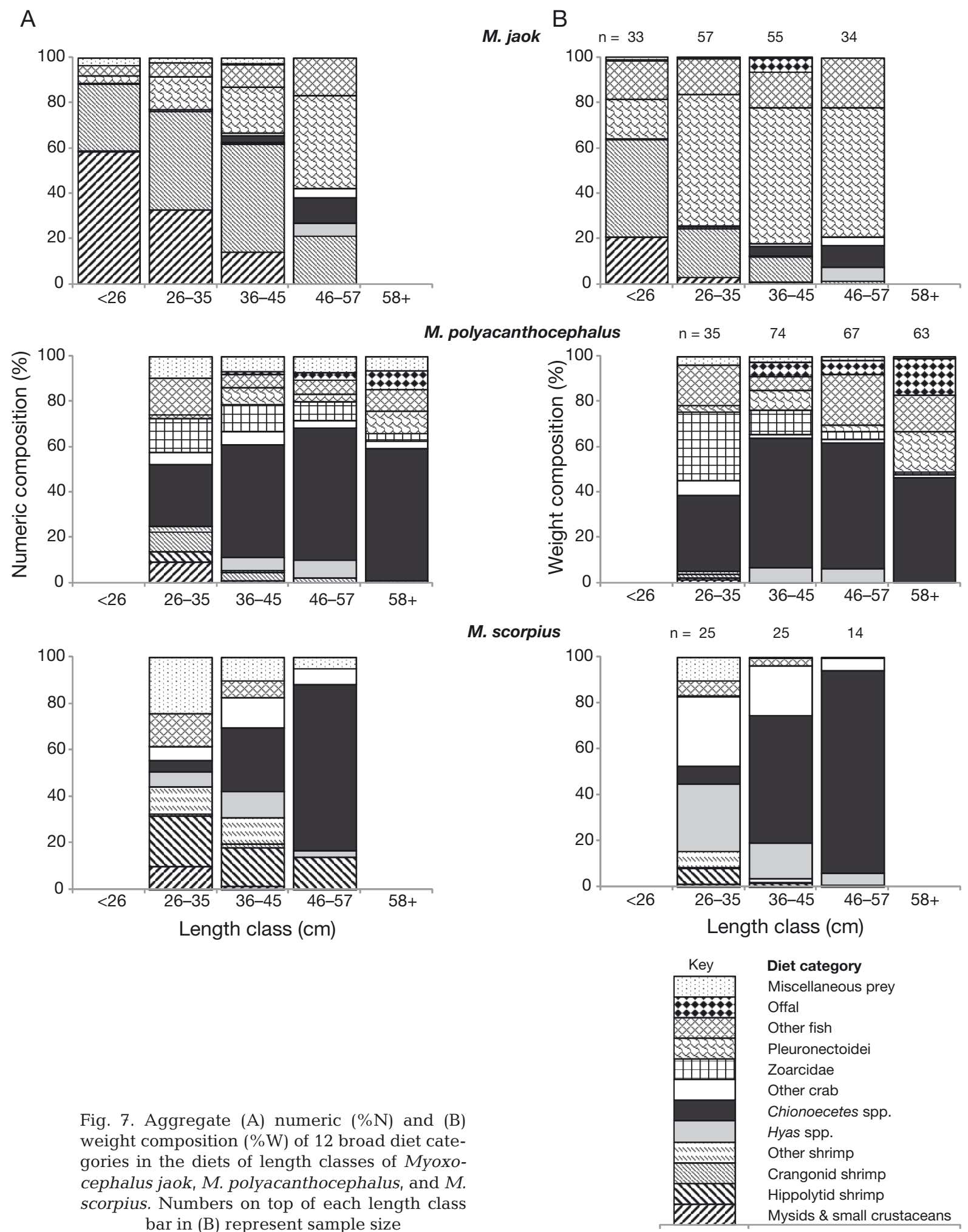

M. scorpius

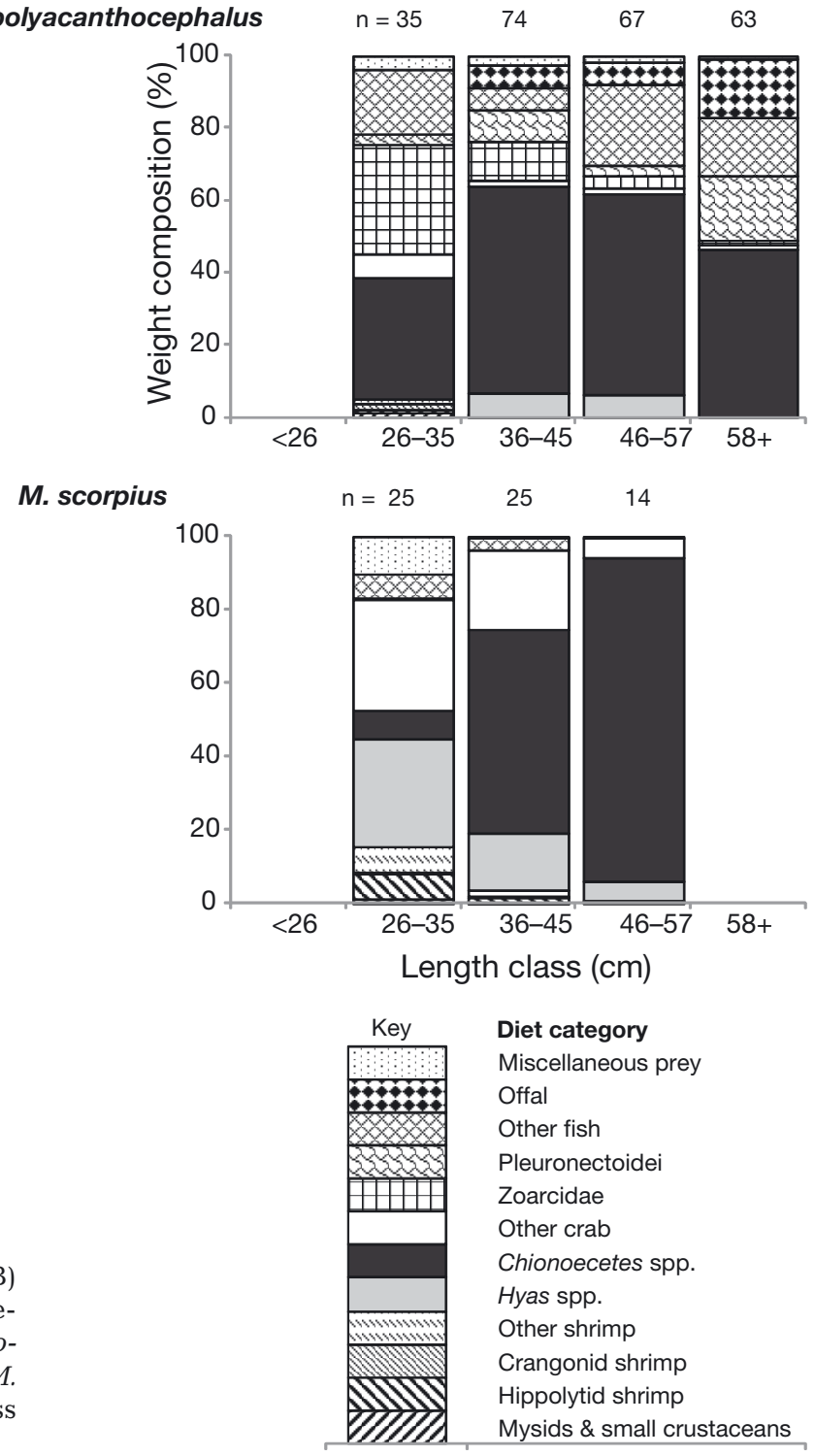

\begin{tabular}{|c|c|}
\hline Key & Diet category \\
\hline \multirow{5}{*}{ 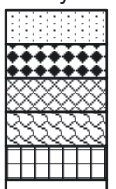 } & Miscellaneous prey \\
\hline & Offal \\
\hline & Other fish \\
\hline & Pleuronectoidei \\
\hline & Zoarcidae \\
\hline & Other crab \\
\hline & Chionoecetes spp. \\
\hline & Hyas spp. \\
\hline & Other shrimp \\
\hline & Crangonid shrimp \\
\hline & Hippolytid shrimp \\
\hline & Mysids \& small crustaceans \\
\hline
\end{tabular}

Fig. 7. Aggregate (A) numeric $(\% \mathrm{~N})$ and (B) weight composition (\%W) of 12 broad diet categories in the diets of length classes of Мyoxocephalus jaok, M. polyacanthocephalus, and $M$. scorpius. Numbers on top of each length class bar in (B) represent sample size 
Table 3. Analysis of similarities (ANOSIM) from intraspecific comparisons of length classes $(\mathrm{cm})$ of 3 Myoxocephalus Bold: R-statistic values; non-bold: associated p-values

\begin{tabular}{|c|c|c|c|c|}
\hline \multicolumn{4}{|l|}{ M. jaok } & $46-57$ \\
\hline$<26$ & & 0.650 & 0.643 & 0.970 \\
\hline $26-35$ & 0.0002 & & 0.106 & 0.882 \\
\hline $36-45$ & 0.0002 & 0.0591 & & 0.493 \\
\hline $46-57$ & 0.0005 & 0.0002 & 0.0005 & \\
\hline \multicolumn{5}{|c|}{ M. polyacanthocephalus } \\
\hline & $26-35$ & $36-45$ & $46-57$ & $58+$ \\
\hline $26-35$ & & 0.271 & 0.509 & 0.707 \\
\hline $36-45$ & 0.0119 & & 0.031 & 0.364 \\
\hline $46-57$ & 0.0002 & 0.2360 & & 0.251 \\
\hline $58+$ & 0.0001 & 0.0001 & 0.0021 & \\
\hline \multicolumn{5}{|c|}{ M. scorpius } \\
\hline & $26-35$ & $36-45$ & $46-57$ & \\
\hline $26-35$ & & 0.684 & 0.949 & \\
\hline $36-45$ & 0.0077 & & 0.487 & \\
\hline $46-57$ & 0.0209 & 0.0483 & & \\
\hline
\end{tabular}

size frequency of Chionoecetes crabs differed among the various length classes of each predator when comparing $M$. polyacanthocephalus and $M$. scorpius (Fig. 8). The 30-45 mm crabs decreased in relative abundance with increasing size of $M$. scorpius, although they appeared to increase in relative importance in the diet. Similarly, crabs smaller than $45 \mathrm{~mm}$ decreased in relative abundance with increasing size of M. polyacanthocephalus; however, they appeared to become relatively less important in the diet for those sculpins $>45 \mathrm{~cm}$. For the $46-55 \mathrm{~cm} \mathrm{M}$. polyacanthocephalus, crabs both smaller and larger than 30-45 mm were relatively more commonly eaten, while the largest sculpins $(56+\mathrm{cm})$ mostly consumed crabs > $45 \mathrm{~mm}$ even though 18-25 mm crabs were relatively common.

Regressions of prey size to predator size indicated a significant increase in prey size with predator size for Myoxocephalus polyacanthocephalus $\left(\mathrm{r}^{2}=0.34\right.$, $\mathrm{p}<0.001)$ and $M$. scorpius $\left(\mathrm{r}^{2}=0.15, \mathrm{p}=0.002\right) . M$. polyacanthochephalus consumed larger Chionoecetes prey than M. scorpius (Mann-Whitney, p < 0.001). When comparing the regression equations with ANCOVA between $M$. polyacanthocephalus and $M$. scorpius, the intercepts differed $(p=0.015)$ but not the slopes ( $\mathrm{p}>0.05)$, suggesting that there was no difference in the rate of consumption of Chionoecetes prey size with increasing predator size.

\section{DISCUSSION}

\section{Distribution}

Myoxocephalus species found in the EBS have farranging geographic distributions (Allen \& Smith 1988, Mecklenburg et al. 2002). In the EBS, these sculpins appear to partition spatially along the shelf by occupying different habitats. The peak abundance of $M$. jaok appeared to be largely limited to the shallower inner shelf. M. polyacanthocephalus exhibited a more homogeneous distribution relative to its congeners, with its distribution extending into deeper waters of the outer continental shelf. These results are similar to what is reported in the western Bering Sea (Tokranov 1981, 1987). Farther north, sculpins contribute a larger proportion of the fish biomass, with $M$. jaok and $M$. scorpius being dominant species (Cui et al. 2009, Stevenson \& Lauth 2012). $M$. scorpius was abundant along the central middle shelf, where a 'cold pool' often exists, and in the NBS, where cold bottom temperatures are found (Cui et al. 2009, Lauth 2011). M. scorpius is considered an Arctic species, having a circumpolar distribution (e.g. Mecklenburg et al. 2002) and antifreeze proteins in its blood (Hew et al. 1980), so it is not unexpected to see a preference for colder environments along the EBS middle shelf. In contrast, it appears that $M$. jaok and $M$. polyacanthocephalus do not prefer colder bottom temperatures, indicating variation in thermal tolerance within this genus.

Based on recent survey data, we found that the overlap in distributions of the 3 species appears to be considerably less than that previously reported (e.g. Allen \& Smith 1988, Mecklenburg et al. 2002). The intensity of interspecific competition may be reduced by the degree to which one species is most dominant along areas of the shelf. As Krebs (1985) noted, species may be unaffected by the presence or absence of others in an area. Niche theory suggests that competitive exclusion is more likely to occur when more of the niches of closely related or competing species overlap, but overlapping of single niche dimensions, biotic or abiotic, appears common between sympatric populations (Wootton 1990)

We found a relationship between mean size at depth and latitude during ontogeny. Reflecting a general trend in fishes, movement of larger fish to deeper waters could be related to the utilization of resources (e.g. larger sized or different prey or predator avoidance) and an increase in longevity (Macpherson \& Duarte 1991). A high abundance of smaller fish, especially those of Myoxocephalus scor- 

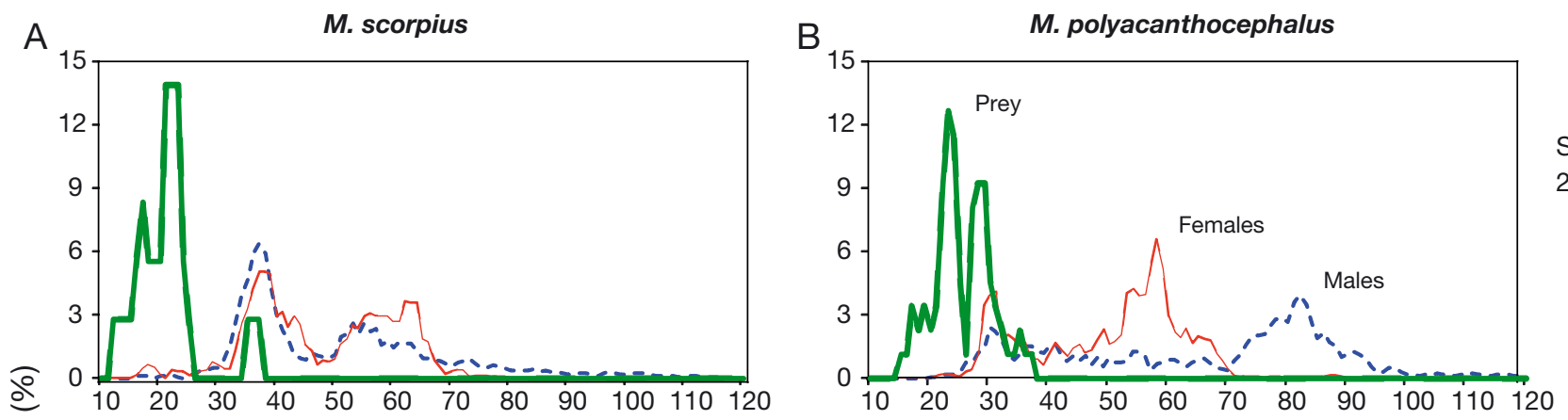

Sculpin

$26-35 \mathrm{~cm}$

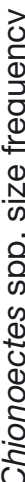
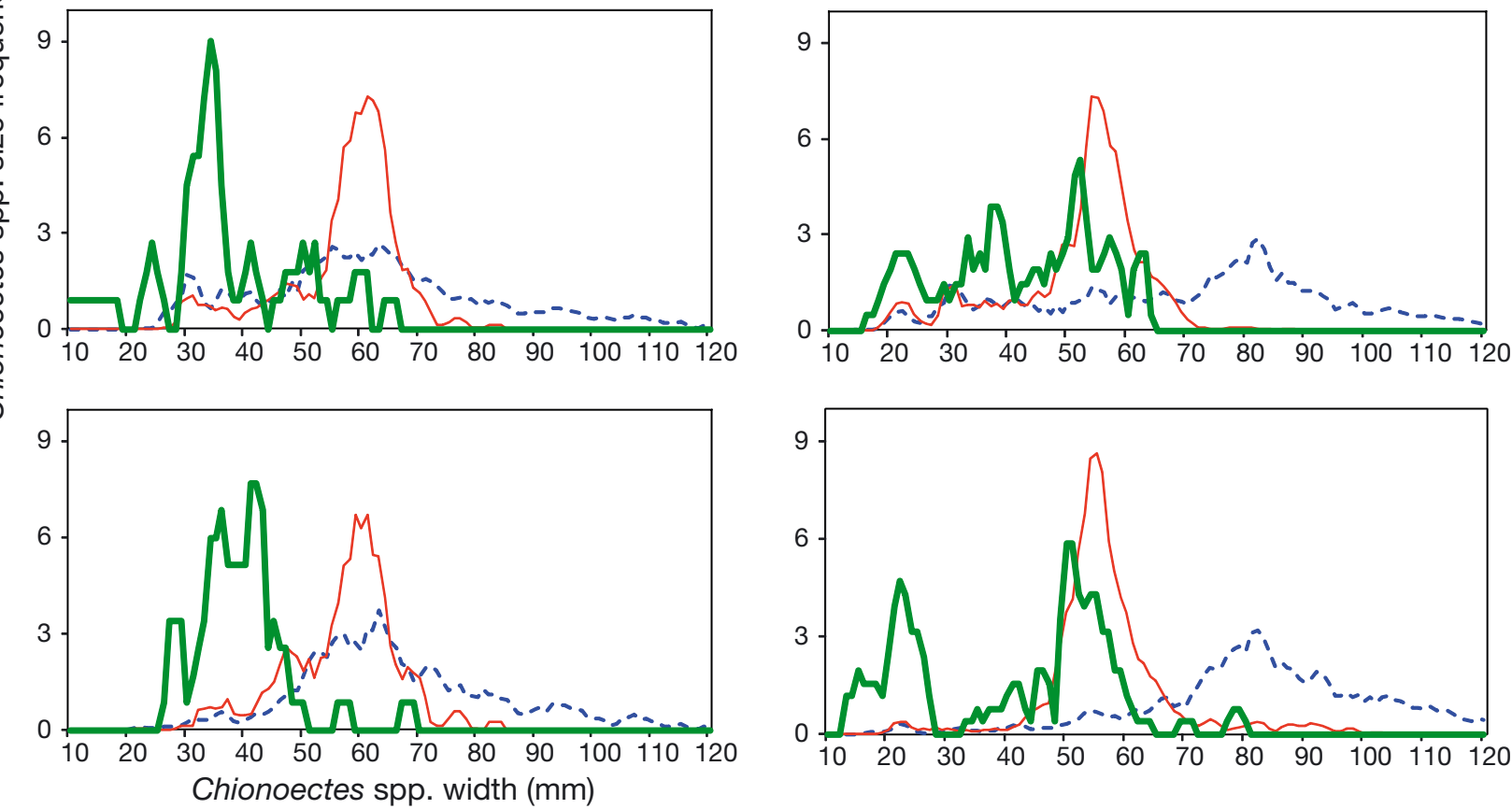

$36-45 \mathrm{~cm}$

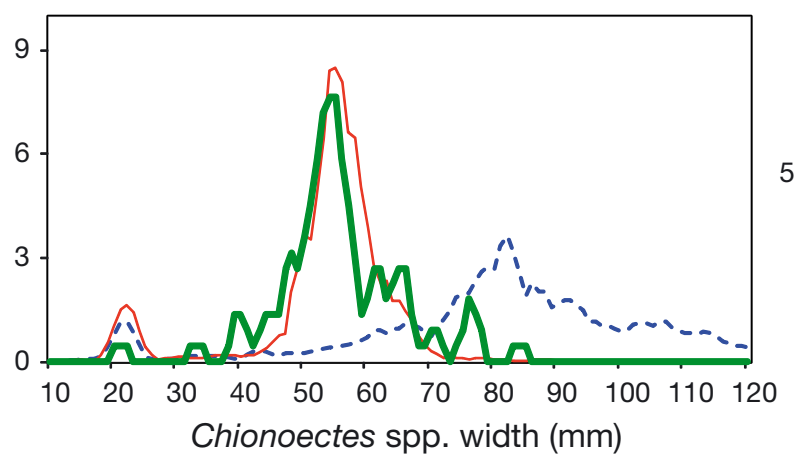

Fig. 8. Size frequency (\%) of Chionoecetes spp. in the diets (green thick line) of (A) Myoxocephalus scorpius and (B) $M$ polyacanthocephalus, and the size frequency of male (blue dashed line) and female (red line) Chionoecetes spp. crabs at stations where predation was found, by each length class $(\mathrm{cm})$ of sculpin

pius by percentage caught, was observed in the NBS, sizes that are almost entirely absent in lower latitudes from standard survey locations using the same sampling trawl gear. Due to prevailing currents, warmer bottom temperatures are found north of St. Lawrence Island than south, where most of the small M. scorpius were caught (Cui et al. 2009, Lauth 2011). These conditions may be more favorable for post-settlement and juvenile $M$. scorpius. Within the Myoxocephalus genus, juveniles might occupy shal-

lower waters in larger numbers than adults due to their ability to tolerate a wider range of temperatures (Panchenko 2003). Juveniles of $M$. polyacanthocephalus occur abundantly in intertidal areas, and juveniles of $M$. jaok are found in high subtidal zones (Cowan 1970). This is consistent with our findings of a general ontogenetic increase in depth.

Environmental conditions can influence species distribution patterns and assemblages. Biotic factors such as prey availability determine the distribution or 
habitat preferences of fish (Mittelbach 2002). Abiotic factors such as depth (Swain 1993, Fujita et al. 1995), often correlated with other indices such as temperature (Rose \& Leggett, 1989), are also strongly associated with demersal fish assemblages (Bianchi 1991). Along the EBS continental shelf, depth is associated with physiographic and oceanographic features of the 3 domains, but bottom temperatures are not linearly correlated with depth due to the 'cold pool' that is often positioned over the middle domain. Walleye pollock Theragra chalcogramma, a key species in the EBS food web, exhibit markedly decreased abundance in the cold pool (Francis \& Bailey 1983). Flathead sole Hippoglossoides elassadon and northern rock sole Lepidopsetta polyxystra tend to be located further northwest in warm years relative to cold years (Spencer 2008). The cold pool also affects the geographic overlap, and thus predation mortality, between predatory Pacific cod Gadus macrocephalus and juvenile Chionoecetes opilio (Livingston 1989). Large latitudinal shifts in Myoxocephalus distribution, however, have not been observed relative to inter-annual shifts of the cold pool, so there does not appear to be any obvious response to extreme bottom temperatures during warm or cold periods. The relatively static distribution pattern suggests that these large sculpins do not migrate long distances and their distributions result from habitat selection of certain areas along the shelf and multi-year temperature patterns.

\section{Diet}

Myoxocephalus sculpins have diverse diets, with each species consuming a wide array of benthic prey items in the EBS. They feed primarily on large, mobile, epibenthic crustaceans and fishes that tend to be larger as the individual predator size becomes larger. Commercially important prey of these 3 sculpin species included Chionoecetes crabs (especially C. opilio), walleye polloc, and flatfishes (predominately rock sole Lepidopsetta spp.). Previous examinations of Myoxocephalus diets also noted a wide variety of prey in the EBS (Mito 1974, Hosoki 1978, Brodeur \& Livingston 1988) and in Russian waters (Tokranov 1987).

The diets we observed in Myoxocephalus polyacanthocephalus and $M$. scorpius were similar to those found in other EBS studies, while the diet we observed in $M$. jaok was somewhat different. Hosoki (1978) found that the $M$. jaok summer diet was dominated by smelts, but other fishes, flatfish, small crustaceans, and crabs also conspicuously contributed.
Interannual variability in the availability of smelt is the most likely cause for the observed diet difference between this study and our results. Brodeur \& Livingston (1988) found little predation on smelt, but flatfishes were fairly important, and Chionoecetes crabs were the dominant prey type. This high crab predation by $M$. jaok could be due to several factors, including sampling from multiple seasons, sampling only from the middle domain (Brodeur \& Livingston 1988), sampling from larger predators (we found that larger $M$. jaok did eat some crabs), or from sampling misidentified Myoxocephalus specimens (Stevenson \& Hoff 2009). The diet we observed in M. polyacanthocephalus was similar to that reported in other studies regarding the importance of Chionoecetes crabs, walleye pollock, flatfishes, and fishery offal (Mito 1974, Hosoki 1978, Brodeur \& Livingston 1988). However, eelpouts Lycodes spp. and other zoarcids in the diet were not identified in other studies, but we found them to be the most important prey fish of $M$. polyacanthocephalus up to $45 \mathrm{~cm}$. The overall diet we observed for $M$. scorpius is generally similar to that reported from the EBS by Hosoki (1978).

Consideration of predator size appears to be an important factor when describing the diet of Муохоcephalus sculpins, and some of the differences among our results can be attributed to ontogenetic diet shifts. Changes in diet or habitat (or both) during ontogeny are extremely common in fishes (Werner \& Gilliam 1984). When ontogenetic shifts in prey types were found, there was a tendency for the prey types consumed to increase in size, and likely mobility, with increasing size of each Myoxocephalus species. We also found a significant increase in the size of Chionoecetes crabs consumed by $M$. polyacanthocephalus and $M$. scorpius with increasing predator size.

The mortality of Chionoecetes juveniles in the EBS through fish predation is high (Aydin et al. 2007). When Pacific cod and skates Bathyraja spp. are considered (Livingston 1989, Lang et al. 2005), mortality has the potential to limit recruitment success. However, Zheng \& Kruse (2006) make the case that physical transport and environmental conditions may ultimately determine the susceptibility of Chionoecetes year classes to predation in the EBS. Our results indicate that Chionoecetes crabs, particularly C. opilio, are a major prey source for Myoxocephalus polyacanthocephalus and M. scorpius, which consume the smaller sizes of Chionoecetes crabs that are available to them.

In a review of field studies, Ross (1986) concluded that, in fishes, partitioning based on diet is more important than partitioning based on habitat. However, the differences in diet among the 3 Myoxocephalus 
species seem to be attributable primarily to their differences in distribution in the EBS and the prey available within those geographic distributions. M. jaok, primarily inhabiting the inner shelf, generally had the least similar diet among the 3 species and consumed a relatively high number of small crustaceans, mysids, and crangonid shrimp up to the largest length class examined. M. polyacanthocephalus and M. scorpius, both common along the middle shelf, showed heavy predation on Chionoecetes crabs, which are also abundant across the middle shelf. For a given predator size, the sizes of Chionoecetes crabs consumed by $M$. polyacanthocephalus were larger than those consumed by $M$. scorpius. While mouth sizes were not measured in this study, this result is consistent with recognized differences in head shape relative to body length among the species. Mecklenburg et al. (2002) describe the head morphology of $M$. polyacanthocephalus as wide, $M$. scorpius as depressed, and $M$. jaok as narrow and depressed. Based on morphological differences, Cowan (1970) speculated that M. jaok and M. polyacanthocephalus occupy somewhat different environments, and this contention was supported by our observations of their distribution. Investigation into the relationships among prey Chionoecetes size, predator size, and head and mouth morphology among the EBS Myoxocephalus could prove interesting.

The updated diet information from this study will be used to improve ecosystem and food web-based models, where direct diet analysis for the large sculpin species functional group has been limited. Defining food web structure, such as population shifts arising from changes in prey availability and predation mortality, is a necessary component of fisheries management (Aydin et al. 2007). Future research and analyses of sculpin diet should include sampling during fall and winter months to provide seasonal comparisons. Further sampling would also help clarify their ecological role by looking more closely at competitive interactions such as how feeding habits change in the presence or absence of similar trophic-level predators.

Acknowledgements. We thank all the scientists participating in AFSC surveys responsible for data collection, and A. Whitehouse and R. Hibpshman for stomach analyses. D. Nichol, J. Hoff, S. Gaichas, K. Aydin and 4 anonymous reviewers provided comments that improved this manuscript. The findings and conclusions in the paper are those of the author(s) and do not necessarily represent the views of the National Marine Fisheries Service, NOAA. This study was partially funded by the North Pacific Research Board (NPRB project \#628).

\section{LITERATURE CITED}

Allen MJ, Smith GB (1988) Atlas and zoogeography of common fishes in the Bering Sea and northeastern Pacific. NOAA Tech Rep NMFS 66

Aydin K, Gaichas S, Ortiz I, Kinzey D, Friday N (2007) A comparison of the Bering Sea, Gulf of Alaska, and Aleutian Islands large marine ecosystems through food web modeling. NOAA Tech Memo NMFS-AFSC-178. US Dept of Commerce, Seatlle, WA

Bakkala RG (1993) Structure and historical changes in the groundfish complex of the eastern Bering Sea. NOAA Tech Rep NMFS 114. US Dept of Commerce, Seattle, WA

Bianchi G (1991) Demersal assemblages of the continental shelf and slope edge between the Gulf of Tehuantepec (Mexico) and the Gulf of Papagayo (Costa Rica). Mar Ecol Prog Ser 73:121-140

Brodeur RD, Livingston PA (1988) Food habits and diet overlap of various eastern Bering Sea fishes. NOAA Tech Memo NMFS-NWC 127. US Dept of Commerce, Seattle, WA

Carrasson M, Cartes JE (2002) Trophic relationships in a Mediterranean deep-sea fish community: partition of food resources, dietary overlap and connections within the benthic boundary layer. Mar Ecol Prog Ser 241:41-55

Chilton EA, Armistead CE, Foy RJ (2011) The 2010 eastern Bering Sea continental shelf bottom trawl survey: results for commercial crab species. NOAA Tech Memo NMFSAFSC-216. US Dept of Commerce, Seattle, WA

Clarke KR (1993) Non-parametric multivariate analysis of changes in community structure. J Ecol 18:117-143

Cowan GIMcT (1970) A morphological comparison of two closely related species of the genus Myoxocephalus (Pisces: Cottidae) with notes on their life histories and ecology. Can J Zool 48:1269-1281

Cui X, Grebmeier JM, Cooper LW, Lovvorn JR, North CA, Seaver WL, Kolts JM (2009) Spatial distributions of groundfish in the northern Bering Sea in relation to environmental variation. Mar Ecol Prog Ser 393:147-160

Davis JLD (2000) Spatial and seasonal patterns of habitat partitioning in a guild of southern California tidepool fishes. Mar Ecol Prog Ser 196:253-268

Fairclough DV, Clarke KR, Valesini FJ, Potter IC (2008) Habitat partitioning by five congeneric and abundant Choerodon species (Labridae) in a large subtropical marine embayment. Estuar Coast Shelf Sci 77:446-456

Fortin M, Gurevitch J (1993) Mantel tests: spatial structure in field experiments. In: Sheiner SM, Gurevitch J (eds) Design and analysis of ecological experiments. Chapman \& Hall, London, p 342-359

Francis RC, Bailey KM (1983) Factors affecting recruitment of selected gadoids in the northeastern Pacific and east Bering Sea. In: Wooster WS (ed) Year to year: interannual variability of the environment and fisheries of the Gulf of Alaska and the eastern Bering Sea. Washington Sea Grant, Seattle, WA, p 35-60

Fujita T, Inada T, Ishito Y (1995) Depth-gradient structure of the demersal fish community on the continental shelf and upper slope off Sendai Bay, Japan. Mar Ecol Prog Ser $118: 13-23$

Hammer Ø, Harper DAT, Ryan PD (2001) PAST: paleontological statistics software package for education and data analysis. Palaeontol Electron 4:1-9

Hastie TJ, Tibshirani RJ (1990) Generalized additive models. Chapman \& Hall, London 
Hew CL, Fletcher GL, Ananthanarayanan VS (1980) Antifreeze proteins from the shorthorn sculpin, Мyoxocephalus scorpius: isolation and characterization. Can J Biochem 58:377-383

Hosoki M (1978) Food habits of sculpins in the eastern Bering Sea. BSc thesis, University of Tokai, Shimizu

Hourston M, Platell ME, Valesini FJ, Potter IC (2004) Factors influencing the diets of four morphologically divergent fish species in nearshore marine waters. J Mar Biol Assoc UK 84:805-817

Hyslop E (1980) Stomach contents analysis - a review of methods and their application. J Fish Biol 17:411-429

Krebs CJ (1985) Ecology: the experimental analysis of distribution and abundance. Harper \& Row, NY

Lang GM, Derrah CW, Livingston PA (2005) Groundfish food habits and predation on commercially important prey species in the eastern Bering Sea from 1993 through 1996. Alaska Fisheries Science Center Proc Rep 2003-04 National Marine Fisheries Service Seattle, WA

Lauth R (2011) Results of the 2010 eastern and northern Bering Sea continental shelf bottom trawl survey of groundfish and invertebrate resources. NOAA Tech Memo NMFS-AFSC. US Dept of Commerce, Washington, DC

Livingston PA (1989) Interannual trends in Pacific cod, Gadus macrocephalus, predation on three commercially important crab species in the eastern Bering Sea. Fish Bull 87:807-827

Mabragana E, Giberto DA (2007) Feeding ecology and abundance of two sympatric skates, the shortfin sand skate Psammobatis normani McEachran, and the smallthorn sand skate $P$. rudis Gunther (Chondrichthyes, Rajidae), in the southwest Atlantic. ICES J Mar Sci 64:1017-1027

Macpherson E, Duarte CM (1991) Bathymetric trends in demersal fish size: Is there a general relationship? Mar Ecol Prog Ser 71:103-112

Marshall AD, Kyne PM, Bennett MB (2008) Comparing the diet of two sympatric urolophid elasmobranchs (Trygonoptera testacea Müller and Henle and Urolophus kapalensis Yearsley and Last): evidence of ontogenetic shifts and possible resource partitioning. J Fish Biol 72: 883-898

Mecklenburg CW, Mecklenburg TA, Thorsteinson LK (2002) Fishes of Alaska. American Fisheries Society, Bethesda, MD

Mito KI (1974) Food relationships among benthic fish populations in the Bering Sea. MSc thesis, Hokkaido University, Hakodate

Mittelbach GG (2002) Fish foraging and habitat choice: a theoretical perspective. In: Hart PJB and Reynolds JD (eds) Handbook of fish biology and fisheries. Blackwell Science, Malden, MA, p 251-266

Ormseth OA, TenBrink TT (2010) Assessment of sculpins in the Bering Sea and Aleutian Islands. In: Stock assessment and fishery evaluation report for the groundfish resources of the Bering Sea/Aleutian Islands region. North Pacific Fishery Management Council, Anchorage, AK, p 1537-1570

Panchenko VV (2003) The seasonal bathymetric distribution of the sculpin Myoxocephalus jaok (Cottidae) in the northern part of the Sea of Japan. J Ichthyol 43:751-756

Platell ME, Potter IC (2001) Partitioning of food resources amongst 18 abundant benthic carnivorous fish species in marine waters on the lower west coast of Australia. J Exp Mar Biol Ecol 261:31-54

Editorial responsibility: Nicholas Tolimieri, Seattle, Washington, USA
Rose GA, Leggett WC (1989) Interactive effects of geophysically-forced sea temperatures and prey abundance on mesoscale coastal distributions of a marine predator, Atlantic cod (Gadus morhua). Can J Fish Aquat Sci 46: 1904-1913

Ross ST (1986) Resource partitioning in fish assemblages: a review of field studies. Copeia:352-388

Sala E, Ballesteros E (1997) Partitioning of space and food resources by three fish of the genus Diplodus (Sparidae) in a Mediterranean rocky infralittoral ecosystem. Mar Ecol Prog Ser 152:273-283

Scharf FS, Juanes F, Rountree RA (2000) Predator size-prey size relationships of marine fish predators: interspecific variation and effects of ontogeny and body size on trophic-niche breadth. Mar Ecol Prog Ser 208:229-248

Schumacher JD, Stabeno PJ (1998) The continental shelf of the Bering Sea. In: Robinson AR, Brink KH (eds) The Sea, Vol 11. John Wiley \& Sons, NY, p 789-822

Smith KR, McConnaughey RA (1999) Surficial sediments of the eastern Bering Sea continental shelf: EBSSED database documentation. NOAA Tech Memo NMFS-AFSC 104. US Dept of Commerce, Seattle, WA

Sommerville E, Platell ME, White WT, Jones AA, Potter IC (2011) Partitioning of food resources by four abundant, co-occurring elasmobranch species: relationships between diet and both body size and season. Mar Freshw Res 62:54-65

Spencer PD (2008) Density-independent and densitydependent factors affecting temporal changes in spatial distributions of eastern Bering Sea flatfish. Fish Oceanogr 17:396-410

Stabeno PJ, Bond NA, Kachel NB, Salo SA, Schumacher JD (2001) On the temporal variability of the physical environment over the south-eastern Bering Sea. Fish Oceanogr 10:81-98

Stauffer G (2004) NOAA protocols for groundfish bottom trawl surveys of the nation's fishery resources. NOAA Tech Memo NMFS-F/SPO-65

Stevenson DE, Hoff GR (2009) Species identification confidence in the eastern Bering Sea shelf survey (19822008). Alaska Fisheries Science Center Proc Rep 200904. National Marine Fisheries Service, Seattle, WA

Stevenson DE, Lauth B (2012) Latitudinal trends and temporal shifts in the catch composition of bottom trawls conducted in the eastern Bering Sea shelf. Deep-Sea Res II 65-70:251-259

Swain DP (1993) Age- and density-dependent bathymetric pattern of Atlantic cod (Gadus morhua) in the southern Gulf of St. Lawrence. Can J Fish Aquat Sci 50:1255-1264

Tokranov AM (1981) Distribution of sculpins (Cottidae, Pisces) at the west Kamchatkan shelf during summer. Zool Zh 60:229-237

Tokranov AM (1987) Feeding of great sculpin, Myoxocephalus polyacanthocephalus, and plain sculpin, M. jaok, in coastal waters of Kamchatka. J Ichthyol 26:980-989

Werner EE, Gilliam JF (1984) The ontogenetic niche and species interactions in size-structured populations. Annu Rev Ecol Syst 15:393-425

Wood S (2006) Generalized additive models: an introduction with R. CRC Press, Boca Raton, FL

Wootton RJ (1990) Ecology of teleost fishes. Chapman \& Hall, NY

Zheng J, Kruse GH (2006) Recruitment variation of eastern Bering Sea crabs: climate-forcing or top-down effects? Prog Oceanogr 68:184-2041

Submitted: November 22, 2011; Accepted: June 14, 2012

Proofs received from author(s): September 6, 2012 